\title{
DNA CLADDING WITH INORGANIC SULPHIDE NANOPARTICLES
}

\author{
A. VEKRIS ${ }^{\mathrm{a}}$, A. ROYÈRE ${ }^{\mathrm{b}}$, G. $^{\text {CAMPET }}{ }^{\mathrm{b}}$, E. SELLIER $^{\mathrm{b}}$,

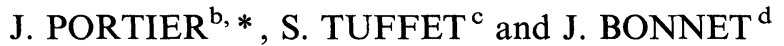 \\ ${ }^{a}$ R. M. S. B., Université Victor Segalen Bordeaux 2, 146 rue Léo \\ Saignat, FR 33076 BORDEAUX Cedex, France; \\ ${ }^{\mathrm{b}}$ ICMCB-CNRS, château Brivazac, FR 33608 Pessac Cedex, France; \\ ${ }^{c}$ ENSCPB, BP 108, avenue pey Berland, FR 33402 Talence Cedex, France; \\ ${ }^{\mathrm{d}}$ Laboratoire d'Immunologie Moléculaire, Université Victor Segalen, \\ 146, rue Léo Saignat, FR 33076 Bordeaux Cedex, France
}

(Received 17 February 1998; In final form 15 April 1998)

\begin{abstract}
The formation of $\mathrm{CdS}$ and $\mathrm{CoS}_{2}$ nanoparticles along the DNA strands have been studied. The systems DNA-Cdl 2 and DNA-CoCl 2 have been investigated in the solid state in order to form DNA-MX $\mathrm{X}_{2}$ complex salts used as precursors. They react with $\mathrm{S}^{2-}$ ions giving birth to $\mathrm{CdS}$ and $\mathrm{CoS}_{2}$ nanoparticles. A model describing the DNAnanosulphide association is proposed.
\end{abstract}

Keywords: DNA; inorganic nanoparticles

\section{INTRODUCTION}

In a recent publication Niemeyer [1] proposed to use biological macromolecules such as proteins or nucleic acids for the construction of nanostructured systems. Such a goal have been actually achieved by Mirkin et al., who rationally assembled gold nanoparticles using oligonucleotides as template [2]. Similar results have been obtained by Alivisatos et al. [3].

During the accomplishment of the present work, Coffer et al., published the preparation of Q-CdS/plasmid DNA nanostructures. In

*Corresponding author. 
this case also, the purpose was to dictate the shape of nanoparticle assemblies by DNA [4].

Another potential application of DNA-nanocomposites could be the non-viral delivery of genes (Fig. 1). Indeed, it is well known that solid particles can penetrate into the cell when their size is adequately small [5]. It is the case for DNA-liposome complexes [6] or DNA immobilised on calcium phosphate [7].

In order to prospect such a potentiality, in a first step, we have developed a method for assembling nanoparticle to DNA. Although the use of toxic $\mathrm{S}^{-}$as a drug is unrealistic, we have chosen, for this initial exploration, cadmium and cobalt sulphides because of the ease of synthesis of isolated quantum-confined nanoparticles.

\section{RESULTS}

DNA, from herring testes, was purchased from ALDRICH. It was solubilized in water $(3,33 \mathrm{~g} / 1) . \mathrm{Cdl}_{2}(\mathrm{ALDRICH}, 99 \%)$ or $\mathrm{CoCl}_{2}$,

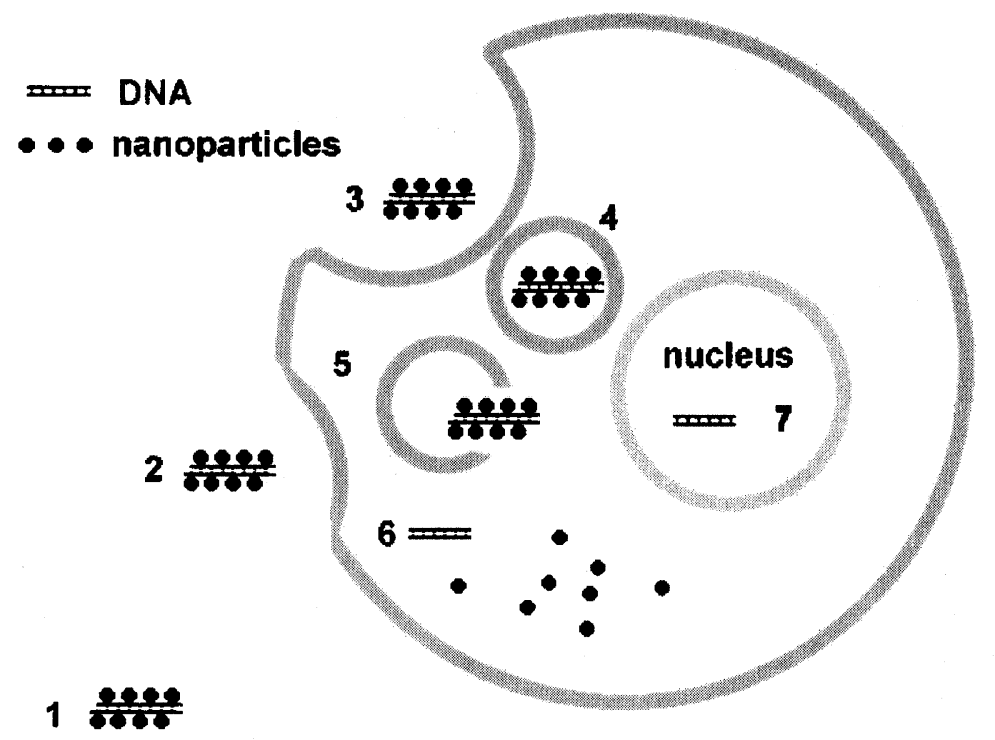

FIGURE 1 Schematic transfection process using a gene cladded by inorganic nanoparticles, in vitro. 1 injection in the culture medium; 2,3,4 phagocytosis of the bio-hybrids; 5 opening of the phagosome; 6 separation of DNA from the inorganic vector (?); 7 internalisation of DNA in the nucleus. 
$6 \mathrm{H}_{2} \mathrm{O}(\mathrm{ALDRICH}, 98 \%)$ were also dissolved in water $\left(\mathrm{C}_{\mathrm{Cd}}=10 \mathrm{~g} / \mathrm{l}\right.$; $\left.\mathrm{C}_{\mathrm{Co}}=5 \mathrm{~g} / \mathrm{l}\right)$. Various amount of the previous solutions were added to the DNA solution.

The precipitation of the complex salts DNA-Cdl 2 or DNA-CoCl $\mathrm{Cl}_{2}$ is observed for an atomic ratio $\mathrm{M} / \mathrm{P}(\mathrm{M}=\mathrm{Cd}, \mathrm{Co})$ close to 0.5 . The solution is evaporated, then dried under vacuum. Colourless transparent films are obtained in the cadmium case or blue for the cobalt. The solubility limit has been determined by XRD that shows the formation of the salt that occurs for an atomic ratio $\mathrm{M} / \mathrm{P}$ of about 1.25 (Fig. 2).

The sulphide nanoparticules have been obtained by soaking the previous $\mathrm{DNA}-\mathrm{MCl}_{2}(\mathrm{M} / \mathrm{P}=1)$ films in a normal solution of ammonium sulphide during 5 seconds. The gels were immediately washed in water until disappearance of ammonium iodide or chloride. Then, they were dried under vacuum. The cadmium and cobalt based films are respectively pale yellow and black.

In this case of cadmium, the compound formed is identified as CdS (wurtzite type). From the width of the XRD lines and using the Scherrer formula, the size of the diffracting smallest particles have been estimated to be $3 \mathrm{~nm}$. The micrographs obtained by TEM confirm this analysis. Indeed, the size of the particles ranges from 2 to $20 \mathrm{~nm}$.

Conversely, in the cobalt case, the DNA- $\operatorname{CoS}_{x}$ composite is amorphous. We have prepared cobalt sulphide using the same experimental conditions but without DNA. The obtained $\mathrm{CoS}_{2}$ compound is crystalline (cattierite type). It is very probable that this compound is also formed in the bio-composite. The TEM micrograph

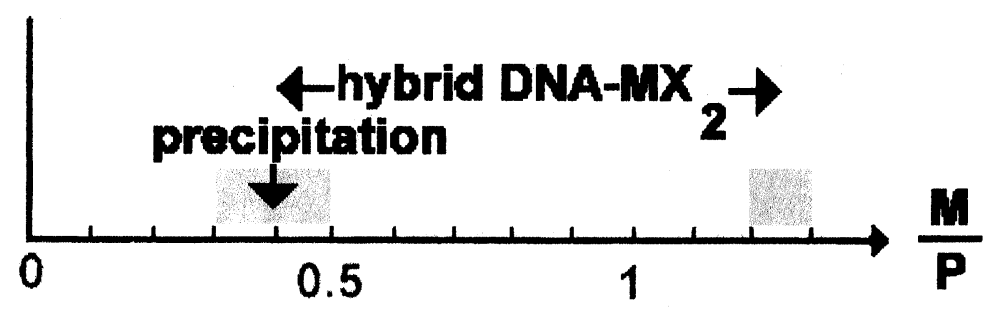

FIGURE 2 Schematisation of the solid state DNA-MX ${ }_{2}$ system. 
evidences the presence of small particles with a diameter ranging from 1 to $15 \mathrm{~nm}$.

\section{DISCUSSION}

The reaction of $\mathrm{S}^{-}$ions onto the cadmium and cobalt DNA complexes leads to a reorganisation of $\mathrm{Co}^{2+}$ and $\mathrm{Cd}^{2+}$ cations along the DNA strands. Varnali and Tözüm-Çalgan [8] calculate the complexation energies for the various basic sites of DNA $\left(-\mathrm{NH}_{2},-\mathrm{CNO}-\right.$, anionic phosphate group) for the interaction of divalent metal cations $\left(\mathrm{Be}^{2+}\right.$, $\mathrm{Mg}^{2+}, \mathrm{Cd}^{2+}, \mathrm{Zn}^{2+}, \mathrm{Hg}^{2+}$ and $\left.\mathrm{Pb}^{2+}\right)$. The highest energy is observed for the phosphate group. Consequently, in this study, it seems conceivable that the nanoparticle are mainly organized around these sites. In addition, the phosphate groups are externally located along the DNA double helix when the other basic sites are internal.

In the cadmium case, taking into account the crystallographic properties of $\operatorname{CdS}\left(V=99,45 \AA^{3}, Z=2\right)$ and the volume of a

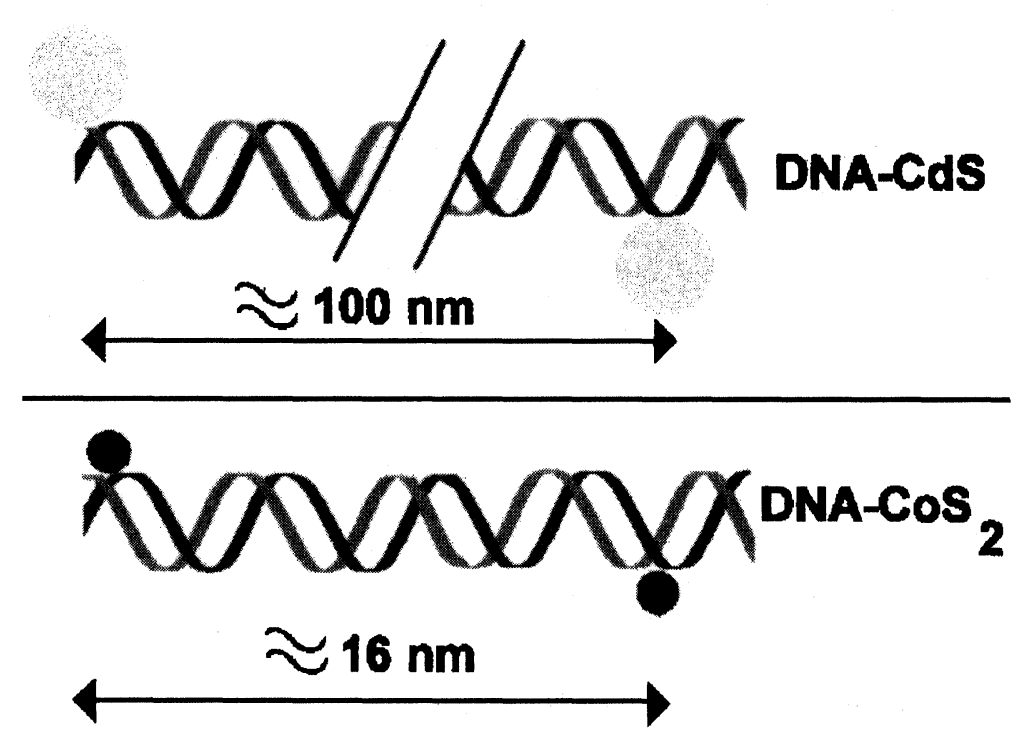

FIGURE 3 Possible organisation of $\mathrm{CdS}$ and $\mathrm{CoS}_{2}$ nanoparticles along double strand DNA. 
nanoparticle $\left(3.3510^{4} \AA^{3}\right)$, it can be estimated that one nanoparticle includes $670 \mathrm{Cd}^{2+}$ ions. As $\mathrm{Cd} / \mathrm{P}=1$ and as there are 20 phosphorus atoms $(\approx 10$ base pairs) per helix turn, it can be assumed that the nanoparticles are far off $100-150 \mathrm{~nm}$ from each other. The same approximation can be done for the cobalt sulphide nanocomposite. In this case the $\mathrm{CoS}_{2}$ nanoparticles would be separated by about 15$20 \mathrm{~nm}$ (Fig. 3).

In fact the proposed inter-nanoparticles distances are correlated to a supposed linear DNA molecules. Actually, it is very probable that the DNA is winded around nanoparticles like it does with proteins. This hypothesis will be investigated in a next future.

\section{References}

[1] Nimeyer Angew, C. M. (1997). Chem. Int. Ed. Angl., 36, n 6, 585.

[2] Mirkin, C. A., Letsinger, R. L., Mucic, R. C. and Storhoff, J. J. (1996). Nature, 382 , 607.

[3] Alivisatos, A. P., Johnsson, K., Peng, X., Wilson, T. E., Loweth, C. J., Bruchez, M. P. Jr. and Schultz, P. G. (1996). Nature, 382, 609.

[4] Coffer, J. L., Bigham, S. R., Li, X., Pinizzotto, R. F., Rho, Y. G., Pirtle, R. M. and Pirtle, I. L. (1996). Appl. Phys. Lett., 69(25), 3851.

[5] Boussif, O., Zanta, M. A., Behr, J. P. and Gene, Ther (1996) Dec; 3(12), pp. 1074 1080.

[6] Lasic, D. D., Strey, H., Stuart, M. C. A., Podgornik, R. and Frederik, P. M. (1997). J. Am. Chem. Soc., 119, 832.

[7] Current protocols in Molecular Biology, Chapter 9.1, F. M. Ausubel, R. Brent, R. E. Kingston, D. D. Moore, J. G. Seidman, K. Struhl (Ed.), John Wiley \& Sons Editor 1998.

[8] Varnali, T. and Tözüm-Çalgan, D. (1995). Structural Chemistry, 6, No 4-5, $343-$ 348 . 

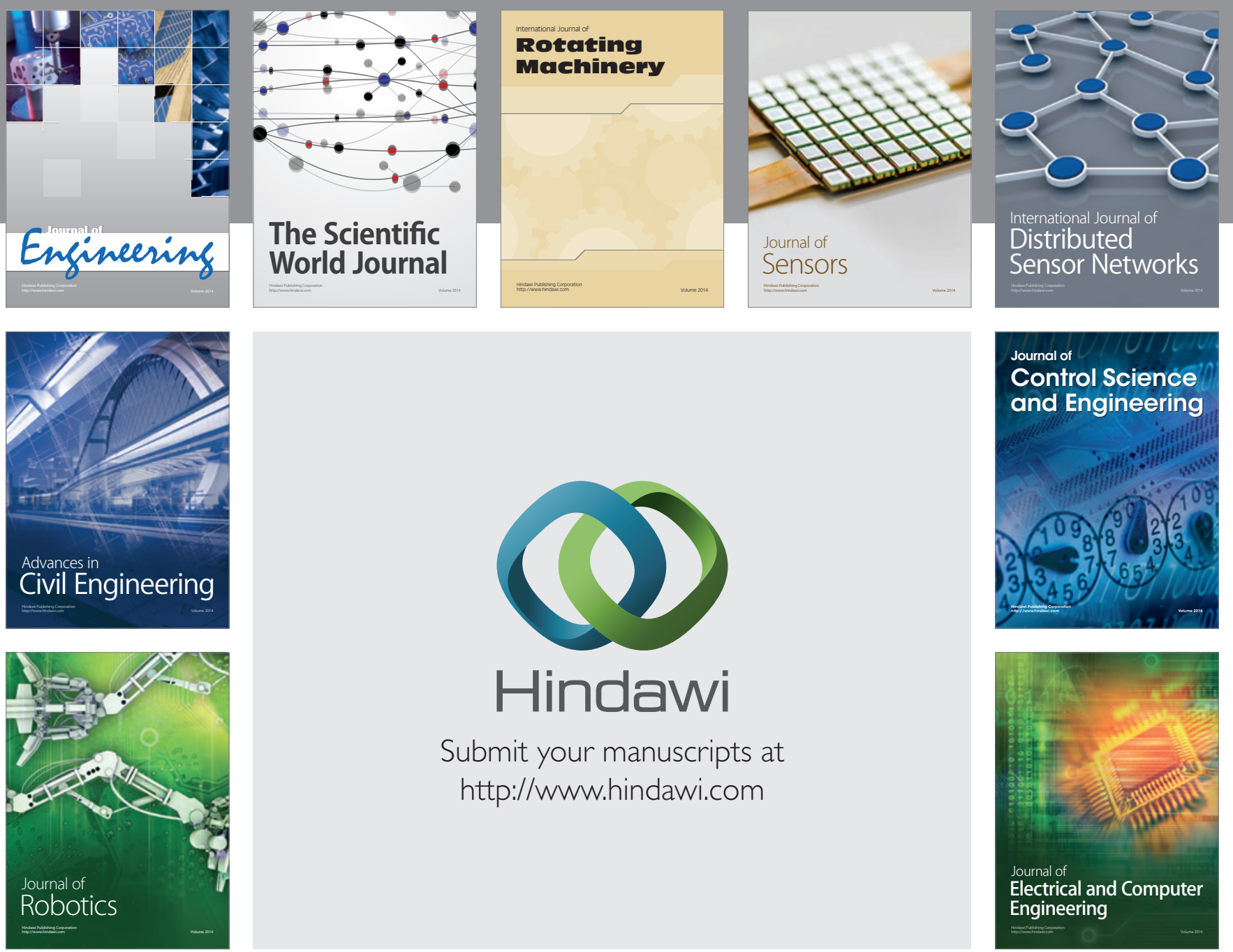

Submit your manuscripts at

http://www.hindawi.com
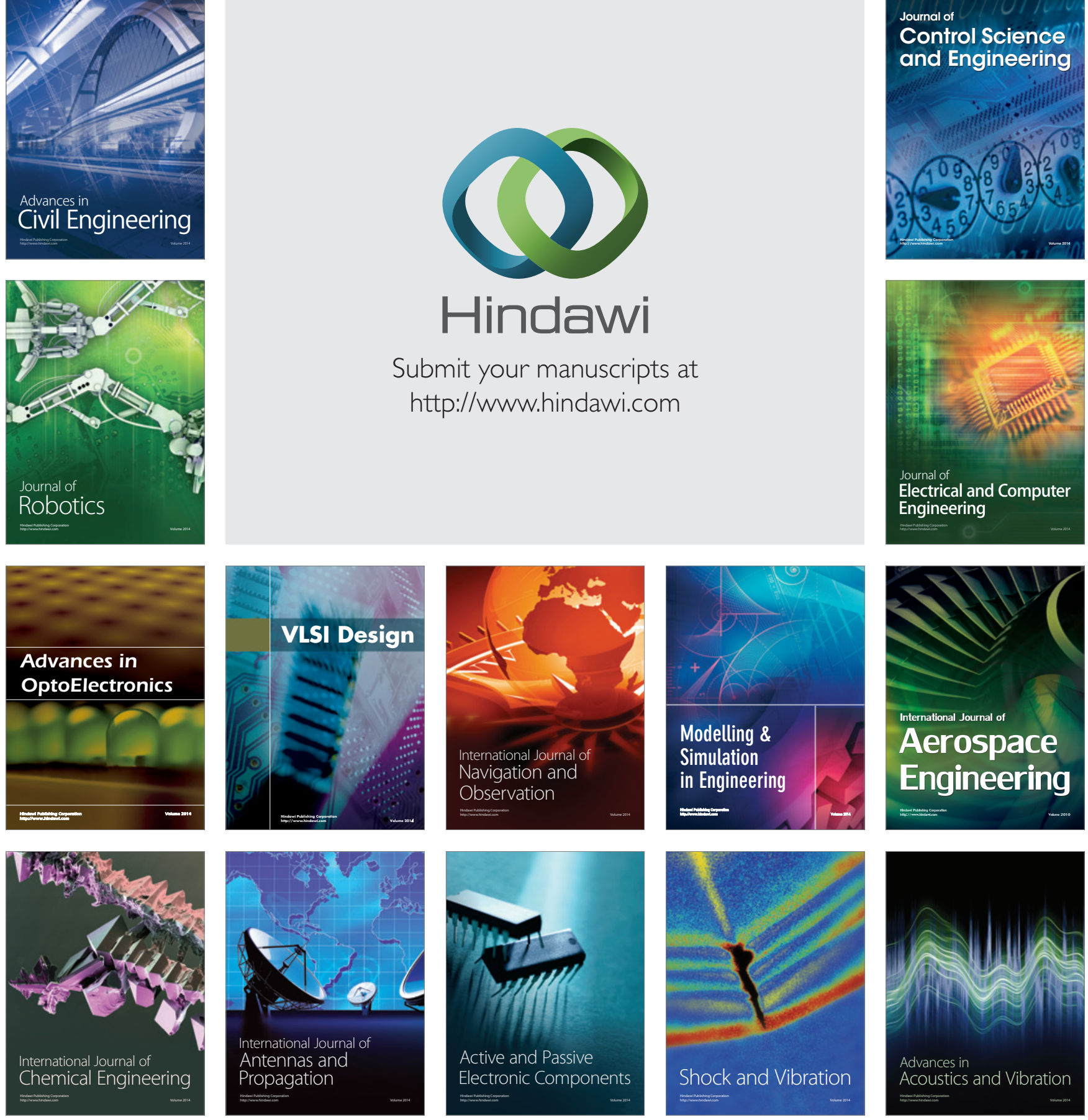